\title{
Analysis of turnover intention power factors: A case study of retail company in Jakarta
}

\author{
Zulfa Fitri Ikatrinasari ${ }^{a^{*}}$, Luhur Prayogo ${ }^{a}$ and Silvi Ariyanti ${ }^{a}$
}

${ }^{a}$ Industrial Engineering, Universitas Mercu Buana, Jakarta, Indonesia

\begin{tabular}{l}
\hline C H R O N I C L E \\
\hline Article history: \\
Received: April 20, 2018 \\
Received in revised format: June \\
21, 2018 \\
Accepted: July 6, 2018 \\
Available online: \\
July 6, 2018 \\
\hline Keywords: \\
Power Factors \\
Turnover \\
PLS \\
Retail company
\end{tabular}

\section{A B S T R A C T}

\begin{abstract}
Employee turnover rate in the head office of retail companies in East Jakarta has been relatively high, recently. The turnover rate results in a disruption of operations in the head office, in forms of delays in the provision of data reporting, which causes a disruption in flow of information. This research covers such aspects as colleagues' relationships, work environment, salary level, job satisfaction, and organizational commitment. The primary objective of this paper is to identify different aspects of employee turnover intention. Partial Least Square Method (PLS) is applied to determine the important factors of employee turnover intention. The result shows that job satisfaction and organizational commitment maintained an adverse and significant effect on turnover intention while salary levels had an adverse but not significant effect on turnover intention. Coworkers and workplace relationships also had an adverse and significant effect but had no direct effect on turnover intention.
\end{abstract}

\section{Introduction}

Retail business in Indonesia in recent years has become a phenomenon in Asia, especially in developing countries (Tolly, 2011). Indonesia even ranks third best retail market in Asia. Based on the records of world management consultant, AT Kearney has had the best retail industry growth report in some countries in the world and in Indonesia. The report with the title "Global Retail Development Index (GRDI, 2015)" assesses the conditions of the retail industry in 30 developing countries in the world and ranks them based on some factors including business risk, population and wealth associated with current retail industry conditions (Bula, 2012). The growth opportunities of retail business are increasingly promising when it is viewed from the ratio of retail and population. Up to now the ratio of local population in Indonesia compared to the population served by the retail is among the lowest in Asia Pacific. In Indonesia, one million new residents are served by 50 retailers including supermarkets, hypermarkets, and minimarkets. The development of this business will become faster, and the rate of employment will also increase. This will make the position of existing retail companies increasingly difficult because they have to maintain an experienced workforces (Ongory, 2007). Employee satisfaction levels should be maintained as high as possible if there is an increase in the number of employees who leave the company due to decreased employee job satisfaction caused by several factors. This obviously will create a higher

* Corresponding author.

E-mail address: zulfa.fitri@mercubuana.ac.id (Z. F. Ikatrinasari)

(C) 2018 by the authors; licensee Growing Science, Canada doi: $10.5267 /$ j.msl.2018.7.002 
cost for companies to recruit and retrain (Hasibuan, 2001). In addition to cost issues, low levels of organizational justice will also cause anxiety for other employees (Mathis, 2004). Organizational justice can create a turnover intention within the company. Turnover intention is a desire to change employees' work with respect (Zeffane, 1994). Suppose employees start looking for reasons to get out of the company for no apparent reason. Employees who have just entered may not necessarily adapt well to the company's organizational environment (Steers, 1977). Besides, the achievements possessed by these new employees may not necessarily exceed or match the accomplishments of previous employees (Mobley, 1986).

The influence of salary level on turnover intention shows that the amount of take-home pay based on position and job is a dimension that has substantial power and has a negative direction toward employee turnover intention (Muthukumaran \& Lavanya Latha, 2013). The same study was conducted on employees at corporate hospitality headquarters. The research showed that the dimensions of salary based on employee performance were strongly influenced and maintained a negative direction toward employee turnover intention (Lee et al., 2013). Other research on the effect of job satisfaction on employee turnover intention shows that the external dimension of job satisfaction had a strong and negative effect on employee turnover intention (Derahman et al., 2014; Janani, 2014). Another study shows that the internal dimension of job satisfaction had a strong and negative direction on turnover intention (Arokiasamy, 2013). The dimensions of corporate values have a negative effect on employee turnover intention (Kalidass \& Bahron, 2015). Other study shows that the internal commitment dimension had a strong influence and negative direction on employee turnover intention (Yamazakia \& Petchdee, 2015). Suharno et al. (2017), found that affective commitment was a dominant influence on turnover intention. Employee commitment, supervisor support and job satisfaction had a significant influence towards turnover intention (Prawirosumarto \& Annur, 2017). From several existing retail businesses, the researcher chose a retail company with convenience store concept which has a head office in East Jakarta as research place. The company has licensed US-traded retailers and started to enter Indonesia in 1986. As of January 2017, the company has managed 512 stores spread across seven operational regions consisting of the Jakarta, Bali, Bandung, Yogyakarta, Batam, Surabaya, and Makassar (Source: Internal Data of the company). Each region has its regional office and also some DC (Distribution Center / Warehouse).

Regional offices in retail companies play a greater role in executing headquarters policies. Ideas and policies generally exist in headquarters. For that we need the data as the basis for top management decisions at headquarters. So the activities at the Head Office do more database-making. Working report is required by top management, and other improvements that are heavily dependent on data and reports made by employees at Headquarters. This reporting data is mainly made by merchandise \& supply chain, business \& business operational development department, and finance department. The overall report data in the company consists of Commercial Reports, Financial Statements, and HR Reports. Data reports vary from daily, weekly, monthly, quarterly, and yearly, and ad-hoc reports. Based on the employee job descriptions at headquarters described above, it appears that the company requires employees to generate reports very much and in a relatively short period of time. So if there are employees who resign, the company will be very disturbed because of the delay in the delivery of reports required for management purposes. Turnover itself is one indicator of assessment in KPI (Key Performance Indicator) company. In the Company Balance Score Card, turnover rates fall into the category of Learning \& Growth, where the target is $5 \%$ for each quarter. However, in the last two quarters, turnover rates were $6 \%$ and $7 \%$ respectively.

\section{Research Method}

The data sources which are used in this research include primary and secondary data. The primary data were obtained from the research questionnaire. The secondary data include employee resignation data, which are obtained from the Human Resource Information System (HRIS) internally after obtaining permission from the company. The technique of collecting data in this research is based on survey using questioner. Questionnaires were distributed among respondents between the period of March 13, 2017, 
and April 28, 2017 (35 working days) at the headquarters of retail companies in East Jakarta. Respondents were asked to answer each item according to their preference. The number of questions in this study was 21 questions. The choice of the statement is adjusted to the Likert scale. The Likert scale is a commonly used scale psychometric in the questionnaire and is the most widely used scale in survey research.

The population of 102 people who were all employees of Head Office, ranging from Senior Manager to Staff level. However, only 100 people were eligible for this survey. This is because two other people just joined the company recently and the survey was interested only in employees with at least six month job experience in the firm. For the application of PLS method the minimum sample size allowed was 30 respondents. The analysis used in this research is Partial Least Square (PLS). In this study, PLS analysis was used to determine the relationship between variables, the power of influence between variables, as well as the significance of these variables (Ghozali, 2013). PLS analysis is part of Structural Equation Modeling (SEM) analysis but with the prediction-oriented approach (Sun, 2011). PLS assumes free distribution for the research data. PLS is an alternative method of SEM that can be used to overcome relationship problems between complex variables with small data size, about 30 to 100 data. PLS uses a bootstrapping or randomly multiplied method. Therefore, the assumption of normality will not be a problem for PLS. In addition for the data normality, bootstrapping does not require a minimum number of samples. Research that has small samples can still use PLS.

\subsection{Research Hypothesis}

Turnover Intention is described as the variables that influence based on field observations. The variables are measured regarding work performance (HRK), work conditions (LK), salary level (LG), job satisfaction (KK), organizational commitment (KO), and turnover intention (IT) itself (Fig. 1). All these variables are then poured into the questionnaire indicator to measure them. Questionnaire was tested for the validity and reliability, then we performed tabulation data.

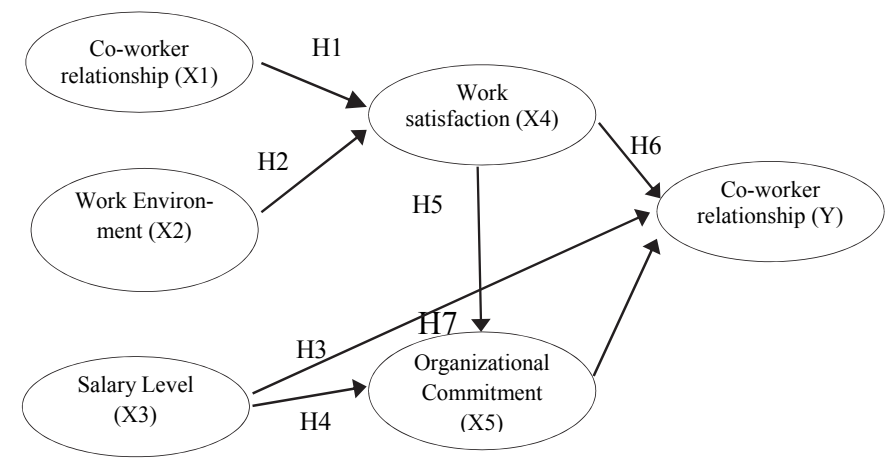

\section{Result and discussion}

Fig. 1. Hypothesis Model

Table 1 shows the value of R-square for each endogenous construct. It can be seen that the amount of Rsquare for work satisfaction construction is 0.709 . This result indicates that the variation of job satisfaction can be explained by the variable of co-worker relationship and work environment of $70.9 \%$, while the rest of $19.1 \%$ is influenced by other variables which are not found in this research model. For the value of R-square, the organizational commitment is 0.501 . This value indicates that the variation of organizational commitment can be explained by job satisfaction variable and salary level of $50.1 \%$, while the rest of $49.9 \%$ is influenced by other variables not found in the research model, while the value of $\mathrm{R}$ square for the turnover intention construction is 0.531 . This value shows that the variation of turnover intention can be explained by job satisfaction variable, the commitment of organization, and salary level of $53.1 \%$, while the rest of $46.9 \%$ is influenced by other variables not found in the research model. 
Tabel 1

The value of $\mathrm{R}$ square in each endogenous construct

\begin{tabular}{lc}
\hline Construct & R Square $\left(\mathbf{R}^{2}\right)$ \\
\hline Work Satisfaction & 0.709 \\
Organizational Commitment & 0.501 \\
Turnover Intention & 0.531 \\
\hline
\end{tabular}

The result of testing the hypothesis between constructs in research model mentioned that all proposed hypotheses are accepted except salary levels against organizational commitment and salary levels against turnover intention (Table 2 and Fig. 2). Job satisfaction had an adverse and significant effect on turnover intention. The organizational commitment had an adverse and significant effect on turnover intention. The salary level had an adverse but not significant effect on turnover intention. The job satisfaction had a positive and significant influence on organizational commitment, salary level had positive but not significant to organizational commitment, co-workers had a positive and significant impact on job satisfaction, and work environment had a positive and significant impact on job satisfaction.

\section{Tabel 2}

Hypothesis Test Research Model

\begin{tabular}{lccc}
\hline & $\begin{array}{c}\text { Coefficient Corre- } \\
\text { lation }\end{array}$ & t-statistic & Hypothesis \\
\hline Co-worker relationship $\rightarrow$ Work Satisfaction & 0.420 & 4.053 & Accept \\
Work Satisfaction $\rightarrow$ Organizational commitment & 0.695 & 8.775 & Accept \\
Work Satisfaction $\rightarrow$ Turnover intention & -0.344 & 3.551 & Accept \\
Organizational commitment $\rightarrow$ turnover intention & -0.436 & 4.552 & Accept \\
Salary level $\rightarrow$ Organizational commitment & 0.029 & 0.309 & Reject \\
Salary level $\rightarrow$ turnover intention & -0.018 & 0.229 & Reject \\
Work Environment $\rightarrow$ Work Satisfaction & 0.461 & 4.360 & Accept \\
\hline
\end{tabular}

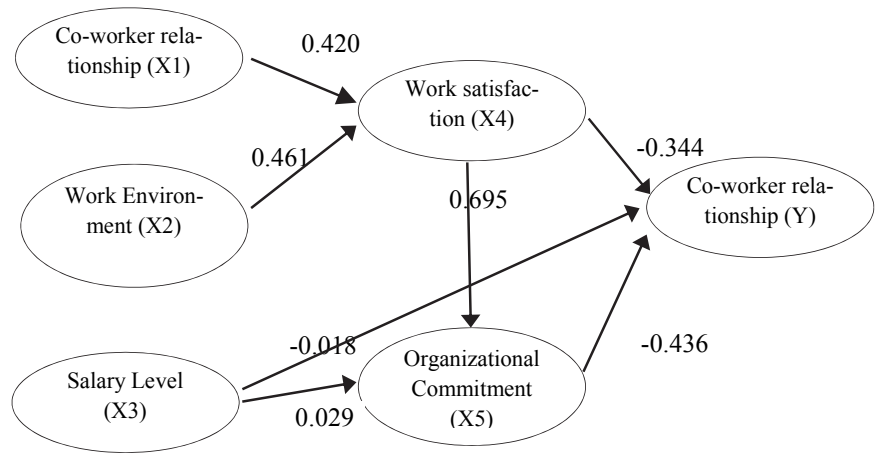

Fig. 2. Partial Least Square Result

\section{Recommendations for Improvement}

All indicators which were used to measure each construct variable is useful to know what aspects have a strong correlation to turnover intention. Corrective action will then be made on those aspects. Data in Table 3 is the value of loading factor or correlation coefficient between each indicator with construct variable. The observed cross section is between an indicator and a turnover intention construct. Based on the above data we can see that the KK3 indicator (clear career path), LK1 (Office stationery, computer, printer, and phone are available), KO3 (the desire to make the company grow), and LK2 (clean and fragrant workspace and floor) loading factor were higher than or equal to 0.6 which means the correlation between the indicator with turnover intention was quite reliable. So the order of proposed improvement can be submitted to aspects:

1. Clarity of career path

2. Office stationery, computer, printer, and phone

3. Cleanliness of workspace 
The KO3 aspect (the desire to make the company grow) is an internal aspect of employees. So no corrective action can be taken by the company.

Tabel 3

Loading Factor Value

\begin{tabular}{lcccccc}
\hline & HRK & LK & LG & KK & KO & TI \\
\hline HRK1 & 0.77 & 0.61 & 0.45 & 0.64 & 0.61 & -0.54 \\
HRK2 & 0.79 & 0.58 & 0.39 & 0.64 & 0.52 & -0.56 \\
HRK3 & 0.74 & 0.65 & 0.19 & 0.60 & 0.63 & -0.54 \\
HRK4 & 0.75 & 0.70 & 0.30 & 0.59 & 0.61 & -0.57 \\
HRK5 & 0.80 & 0.64 & 0.29 & 0.57 & 0.57 & -0.57 \\
\hline LK1 & 0.71 & 0.79 & 0.37 & 0.67 & 0.72 & $\mathbf{- 0 . 6 3}$ \\
LK2 & 0.65 & 0.79 & 0.29 & 0.58 & 0.59 & $\mathbf{- 0 . 6 0}$ \\
LK3 & 0.68 & 0.80 & 0.32 & 0.66 & 0.67 & -0.54 \\
LK5 & 0.52 & 0.69 & 0.16 & 0.52 & 0.44 & -0.48 \\
\hline LG1 & 0.40 & 0.34 & 0.86 & 0.38 & 0.28 & -0.28 \\
LG2 & 0.32 & 0.30 & 0.85 & 0.35 & 0.30 & -0.25 \\
LG3 & 0.34 & 0.31 & 0.82 & 0.36 & 0.24 & -0.23 \\
\hline KK1 & 0.63 & 0.62 & 0.34 & 0.84 & 0.58 & -0.50 \\
KK2 & 0.64 & 0.61 & 0.34 & 0.77 & 0.53 & -0.47 \\
KK3 & 0.70 & 0.69 & 0.38 & 0.85 & 0.62 & $\mathbf{- 0 . 6 3}$ \\
\hline KO1 & 0.65 & 0.67 & 0.29 & 0.61 & 0.82 & -0.52 \\
KO2 & 0.57 & 0.63 & 0.18 & 0.53 & 0.81 & -0.53 \\
KO3 & 0.63 & 0.61 & 0.32 & 0.58 & 0.82 & $-\mathbf{0 . 6 0}$ \\
\hline TI1 & -0.55 & -0.48 & -0.30 & -0.55 & -0.50 & 0.78 \\
TI2 & -0.57 & -0.51 & -0.23 & -0.48 & -0.51 & 0.53 \\
TI3 & -0.51 & -0.64 & -0.15 & -0.44 & -0.53 & 0.72 \\
\hline
\end{tabular}

\section{Conclusion}

Based on the measurement of the factors driving the employee turnover intention in a retail company headquartered in East Jakarta, there are several conclusions:

1. Satisfactory has significant impact on turnover intention.

2. Organizational commitment has a significant adverse impact on turnover intention.

3. The salary level affects the adverse and insignificant effect on turnover intention.

3. Job satisfaction and salary level positively and positively impact on organizational commitment.

4. There is a relationship between work and work environment and positively impacts on job satisfaction.

It is necessary to measure the influence of career path indicators, availability of work support facilities (Office stationery, computers, printers, and telephones), cleanliness of the workspace, and the desire to make the company more developed to know more about the direction of the relationship and the effect on turnover intention.

\section{References}

Arokiasamy, A. R. A. (2013). A qualitative study on causes and effects of employee turnover in the private sector in Malaysia. Middle-East Journal of Scientific Research, 16(11), 1532-1541.

Derahman, R., Fadzil, N.H.M., \& Aziz, N.A. (2014). Turnover contagion: Attract and retaining talents in retail employment. Australian Journal of Basic and Applied Sciences, 8(20), 22-26.

Ghozali, I. (2013). Aplikasi Analisis Multivariate dengan Program SPSS, Edisi Ketiga. Semarang: Badan Penerbit Universitas Diponegoro.

Hasibuan, M. (2001). Manajemen Sumber Daya Manusia. Jakarta: Bumi Aksara.

Jewell, L. N. \& Siegall, M. (1998). Psikologi Industri Organisasi Modern. Terjemahan. Jakarta: Arcan. Irshad, M., \& Afridi, F. (2007). Factors affecting employees retention: Evidence from literature. Abasyn Journal of Social Sciences, 4(2), 307-339.

Janani, S. (2014). Employee turnover: Present scenario of Indian IT industry. Indian Journal of Applied Research, 4(3), 254-256. 
Kalidass, A., \& Bahron, A. (2015). The relationship between perceived supervisor support, perceived organizational support, organizational commitment and employee turnover intention. International Journal of Business Administration, 6(5), 82.

Muthukumaran, M., \& Lavanya Latha, K. (2013). Reducing employee turnover: A Retention strategy. Acta de Gerencia Ciencia, 1(2), 21-26.

Lee, C. C., Huang, S. H., \& Zhao, C. Y. (2012). A study on factors affecting turnover intention of hotel empolyees. Asian Economic and Financial Review, 2(7), 866.

Mathis, R. (2004). Manajemen Sumber Daya Manusia, Human Resource Management. Jakarta: PT Salemba Emban Patria.

Mobley, W. (1986). Pergantian Karyawan: Sebab Akibat dan Pengendaliannya. Jakarta: PT. Pustaka Binaman Pressindo.

Ongory, H. (2007). A review of the literature on employee turnover. African Journal of Business Management, 1(3), 49-54.

Bula, H. O. (2012). Labor turnover in the Sugar Industry in Kenya. European Journal of Business and Management, 4(9), 145-152.

Ozola, I. (2015). Reducing Employee Turnover in Small Business. Journal of Mathematics and Computers in Sciences and Industry, 12(8), 21-34.

Prawirosumarto, S. \& Annur, M.I. (2017). The Influence of Employee Commitment, Supervisor Support, and Job Satisfaction towards Turnover Intention at Ciriajasa Engineering Consultant Co., Ltd. International Journal of Management and Administrative Science (IJMAS), 4(7), 21-33.

Rusdi, M. Hubeis, A.V.S., Affandi, J.M. \& Dharmawan, A.H. (2015). Employee turnover intention in indonesian banking. International Journal of Information Technology and Business Management, 38(1), 31-36.

Saeed, I., Waseem, M. \& Sikander, S. (2014). The relationship of turnover intention with job satisfaction, job performance, and organizational commitment. International Journal of Learning and Development, 4(2), 242-256.

Salleh, R., Nair, M. S., \& Harun, H. (2012). Job satisfaction, organizational commitment, and turnover intention: A case study on employees of a retail company in Malaysia. World Academy of Science, Engineering and Technology, 72(12), 316-323.

Sandhya, K., \& Kumar, D. P. (2011). Employee retention by motivation. Indian Journal of science and technology, 4(12), 1778-1782.

Suharno, P., Ketut, S., Setyadi, S., \& Farida, E. (2017). The effect of organizational commitment toward turnover intention at Narada school, Indonesia. Russian Journal of Agricultural and Socio-Economic Sciences, 62(2), 55-66.

Sun, K. S. (2011). The turnover intentions for construction engineers. Journal of Marine Science and Technology, 19(5), 550-556.

Steers, R. M. (1977). Antecedents and outcomes of organizational commitment. Administrative science quarterly, 22(1), 46-56.

Tolly, A. (2011). Analisis Faktor-Faktor yang mempengaruhi Turnover Intention pada Staf Supermarket. Jurnal Akuntasnsi dan keuangan, 3(2), 102-105.

Yamazakia, Y. \& Petchdee, S. (2015). Turnover intention, organizational commitment, and specific job satisfaction among employees in Thailand. Journal of Business and Management, 4(4), 22-38.

Zeffane, R. (1994). Understanding employee turnover: The need for a contingency approach. International Journal of Manpower, 15(9), 1-14.

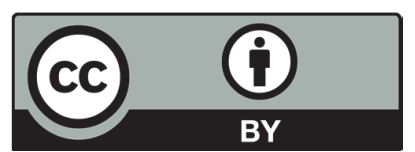

(C) 2018 by the authors; licensee Growing Science, Canada. This is an open access article distributed under the terms and conditions of the Creative Commons Attribution (CCBY) license (http://creativecommons.org/licenses/by/4.0/). 